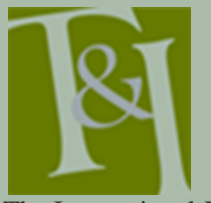

The International Journal for Translation \& Interpreting Research trans-int.org

\title{
Introduction: Special issue on the history of translation and interpreting
}

\author{
Myriam Salama-Carr \\ University of Manchester \\ myriam.salama-carr@manchester.ac.uk
}

DOI: 10.12807/ti.111202.2019.a01

Over the last two decades translation studies has expanded the spatial boundaries of its historical research, in a move towards inclusiveness and with a view to foregrounding less visible and uncharted traditions (Cheung, 2009, 2012; Gaddis Rose, 2000; Hermans, 2006; amongst others), which is linked with the 'international turn in translation studies' (Cheung, 2005). The development of historical research on translation thinking and praxis is largely tributary to the crossing of disciplinary boundaries, for instance the role of gender studies and postcolonial studies in researching hitherto neglected voices and constituencies.

Research in the history of translation has not only helped foreground the role of translation in the transmission and construction of knowledge across spatial and temporal boundaries, but it is also seen as a means of studying wider cultural history (Rundle, 2012). Gaps remain, nevertheless, in terms of lesser researched traditions and modes of mediation. One such gap can be found in the history of interpreting given the scarcity of sources for historians.

A number of scholars have raised the issue of how to carry out research in the field with due attention to epistemological and methodological challenges (Delisle, 1997; D'hulst, 1995; Pym, 1998) and more recent studies, drawing on a wider range of translation and interpreting histories, have problematised further the discourse on translation in terms of metalanguage, periodisation and underlying assumptions (Cheng, 2007, 2014; D'hulst, 2007, 2014; Foz, 2006; O'Sullivan, 2012; Wakabayashi \& Kothari, 2009). It is therefore particularly timely that a new open access journal, Chronotopos, is dedicated to this field of inquiry, with a much sharper focus on the way historiography and history of translation is carried out.

The special issue brings together a collection of articles which offer a critical exploration of translation mediation and cultural encounters in a variety of historical and linguistic settings, providing further insights on past practices and conceptualisations of translation and interpreting, of translator and interpreter agency, and reflecting on the role of language mediation in nationbuilding and the construction of identity.

The rich and complex translation movement of the nahda, the Arab cultural revival of the $19^{\text {th }} /$ early $20^{\text {th }}$ century, forms the backdrop to Rafik Jamoussi and Konstantinos Kritsis' article, "Another scattered pearl: I. A. I Barsoum's risālah fí usūl al ta 'rīb 'an al siriānīah", which foregrounds an Arabic treatise - the risālah fì usūl al ta 'rīb 'an al siriānīah [Epistle on translation principles from Syriac into Arabic] of the title - dealing with the translation of Syriac texts, mainly religious, into Arabic. The treatise itself expounds views on translation requirements, with particular focus on translation accuracy, fidelity and freedom and terminological precision. Their study sheds new light on yet another perspective of the nahda translation scene, namely that of cultural 
legacy and inclusion in a context of diglossia and minority languages, and contributes to the historiography of translation.

The centrality of language and translation to the construction of national identity is also the focus of Alexandra Hillinger's account of "The status of the French language in British North America: From the Conquest to the Confederation". The article addresses the evolution of the French language in Canada and examines its impact on policy and practice. Drawing on archival work, the author shows how translation was key to safeguarding the linguistic rights of French Canadians, and thus contributes to the history of translation in its Canadian context and resonates with the recent moves to enshrine language rights in human rights.

Research in the history of translation and interpreting has increasingly addressed the challenges of periodisation and historicization. Marlon James Sales' "Translation (in/of/as) history in Hispanic Filipino literature" shows how translation, which is central to the mediation of text, contributes to the creation of national narratives. Unpacking the dissemination of Hispanic Filipino literature to national readership through translation, the author shows how the writing of translation histories calls for translation to be viewed as material, method and mode of commemoration.

Isis Herrero López addresses the major issue of periodization in histories of translation, focusing on literary production to problematize further conceptualisations of time and periods in translation studies which tend to map onto existing literary and cultural chronologies. The author reviews some of the main approaches to temporality in the field and reflects critically on her own use of periodization when examining the history of the translation of Jane Austen's works in Spain.

In "Rethinking the interpreter's agency", Lucía Ruiz Rosendo explores the interpreter's agency in wartime and focuses on the memoirs of a Swiss interpreter who had worked for the Gestapo and played an ambivalent mediation role. In addition to drawing a historically valuable portrait of an interpreter - a case-study in terms of interpreters' involvement in the war machine - the article unpacks the psychological tension and ethical issues that underpin the agency of the interpreter in a situation of conflict.

$\mathbf{M}^{\mathrm{a}}$ Carmen África Vidal Claramonte's article, "Translating oral microhistories ethically: the case of Elena Poniatowska", focuses on a text of hybrid fiction and personal accounts, Poniatowska's La Noche de Ttaleco, which relates historical events which took place in Mexico in the late 1960s. The article echoes the increased interest shown by translation studies scholars in microhistories and personal narratives. History here is seen as translation. The article foregrounds the ethical dimensions of the dissemination of microhistories, notably via translation, and in this instance, with specific reference to the English translation of La Noche de Ttaleco.

The part played by translation in the construction and dissemination of science is increasingly acknowledged and researched within translation studies, and María Pilar Castillo Bernal's article, "The translation of scientific literature from German into Spanish at the turn of the $20^{\text {th }}$ century", sheds light on the historical importance of languages other than English as languages of science. The article examines the work of translators for Spanish scientific journals, providing a wealth of examples drawn from Spanish translations of German writings on biochemistry and microbiology, and identifies the use of various techniques which point to a high degree of adaptation.

Taking as a point of departure the focus of traditional translation scholarship on religious, literary and philosophical texts, Heleen van Gerween sets out to address the under-researched role of institutional and legal translation in the history and historiography of translation. "Describing and Explaining legal Translations in History: the case of $19^{\text {th }}$ century Belgium" offers an interdisciplinary perspective, drawing on legal and social history as well as 
translation studies, to study legal translation practices and their socio-cultural impact in terms of citizens' access to legislation and their participation in political life.

In "Translating to change the nation: the case of José Pedro Varela, a reformer in late $19^{\text {th }}$ century Uruguay", Gabriel González Núñez explores a less-researched period in the history of translation, that of the Independence and Republic period, by focusing on José Pedro Varela, an educational reformer in $19^{\text {th }}$ century Uruguay. The article shows how much of Varela's work consisted of translations, and helps to foreground the role of the translator in educational reform and nation-building. Moreover, the discussion sketches the debate on translation in a context where the boundaries between authorship and translation were often blurred.

The articles mentioned thus far are all adding to the body of knowledge on the history of translation and interpreting, whilst illustrating the interdisciplinary and multidisciplinary nature of the field and raising or critically reviewing some of its methodological and conceptual tenets. It seems fitting to conclude with Judy Wakabayashi's illuminating discussion of digital humanities, where new approaches and tools are presented and evaluated. The input and potential impact of technology on translation and interpreting practice has been debated (Pym, 2011; see also Devaux, 2018) but the growth of digital humanities has opened up research avenues and tools for historians and historiographers of translation. "Digital approaches to translation history" discusses the potential of digital text analysis and data visualisation, amongst others, for the study of translation history and for the dissemination of scholarship to a wider public.

\section{References}

Cheung, M. (2003). From theory to discourse. The making of a translation anthology. Bulletin of the SOAS, 66(3), 390-401

Cheung, M. (2005). 'To translate' means 'to exchange? A new interpretation of the earliest Chinese attempts to define translation ('fanyi'). Target, 17(1), 27-47

Cheung, M. (2007). On thick translation as a mode of cultural representation. In D. Kenny \& R. Kyongjoo (Eds.), Across boundaries: International perspectives on Translation Studies (pp. 22-36). Newcastle, UK: Cambridge Scholars.

Cheung, M. (2009). Introduction - Chinese discourses on translation: Positions and perspectives. The Translator, 15(2), 223-238.

Cheung, M. (2012). The mediated nature of knowledge and the pushing-hands approach to research on translation history. Translation Studies, 5(2), 156-171.

Cheung, M. (2014). An anthology of Chinese discourse on translation $\left(2^{\text {nd }} \mathrm{ed}\right)$. London $\&$ New York: Routledge.

Delisle, J. (1997). Réflexions sur l'historiographie de la traduction et ses exigences scientifiques [Reflecting on translation historiography and its scientific requirements]. Equivalences, 26 (2), 21-43

Devaux, J. (2018). Technologies and role-space: how video-conference interpreting affects the court interpreter's perception of her role. In C. Fantinuoli (Ed.), Interpreting and technology (pp. 91-117). Berlin: Language Science Press.

D'hulst, L. (1995). Pour une historiographie des théories de la traduction : questions de méthode [Towards a historiography of translation theories : Methodological issues]. TTR, 8(1), 13-33.

D'hulst, L. (2007). Questions d'historiographie de la traduction [Issues of translation historiography]. In H. Kittel, A. P. Frank, N. Greiner, T. Hermans, W. Koller, J. Lambert \& F. Paul (Eds.), Ubersetzung Translation Traduction (pp. 1063-1073). Berlin \& New York: Walter de Gruyter.

D'hulst, L. (2014). Essais d'histoire de la traduction-Avatars de Janus [Essays on the history of translation - Janus Avatars]. Paris: Classiques Garnier.

Foz, C. (2006). Translation, history and the translation scholar. In P.F. Bandia \& G. L. Bastin (Eds.), Charting the future of translation history (pp 131-143). Ottawa: University of Ottawa Press. 
Gaddis Rose, M. (Ed.) (2000). Beyond the Western Tradition. Translation perspectives XI. Binghamton: Center for Research in Translation - State University of New York.

Hermans, T. (Ed.) (2006). Translating others. (Vols. 1-2). Manchester: St Jerome.

O’Sullivan, C. (Ed.) (2012). Translation Studies - Special Issue on Rethinking Methods in Translation History, 5(2).

Pym, A. (2011). What technology does to translating. The Translation and Interpreting Journal. 3(1), 1-9.

Rundle, C. (2012). Translation as an approach to history. Translation Studies, 5(2). 232240.

Wakabayashi, J. \& Kothari, R (Eds.). (2009). Decentering Translation Studies - India and beyond. Amsterdam \& New York: John Benjamins. 